\title{
Growth and gas exchange of Tachigali vulgaris submitted to water deficiency
}

\section{Crescimento e trocas gasosas de Tachigali vulgaris submetida à deficiência hídrica}

\author{
Wander Ataíde, Cândido Neto, Karollyne Silva, Ana Brito, Kerolém Cardoso, Glauco Nogueira, \\ Thays Costa, Tamires Oliveira, Jéssica Martins and Liliane Machado
}

Instituto de Ciências Agrárias da Universidade Federal Rural da Amazônia, Av. Presidente Tancredo Neves, 2501 - Cep: 66.077-830 - Belém/PA - Brazil

(*E-mail: glauand@yahoo.com.br)

http://dx.doi.org/10.19084/RCA17231

Received/recebido:2017.09.05

Received in revised form/recebido em versão revista: 2018.02.16

Accepted/aceite: 2018.03.27

\begin{abstract}
A B S T R A C T
Tachigali vulgaris L.G. Silva \& H.C. Lima is a pioneer species, colonizer of marginal lands and road margins, which often initiates secondary succession in open areas by the intense germination of their seeds in the soil. Studies on fastgrowing Amazon forest species are very scarce, when it refers to the influence of abiotic factors on an ecophysiology of the species. The experiment was conducted in a greenhouse belong to laboratory of Estudos da Biodiversidade de Plantas Superiores of the Federal Rural University of Amazonia. The experiment was completely randomized in split plot scheme, two times: five and ten days of water suspension, and two water conditions: control and water deficit, with four replications with one plant/pot. The water deficiency condition for ten days negatively affected the growth and indicators of gas exchange (A, gs and E). Adding to the fact that the experiment occurred in a year of extreme climatic anomaly (El Niño), the plants did not resist and perished in the internal conditions of greenhouse. The water deficiency condition altered the growth parameters and the environmental relations of the Tachigali vulgaris species, thus evidencing its low physiological plasticity to this abiotic condition.
\end{abstract}

Keywords: Photosynthesis, conductance, dry mass, white Tachi.

\section{R E S U M O}

Tachigali vulgaris L.G. Silva \& H.C. Lima é uma espécie pioneira, colonizador de terrenos marginais e margens de estradas, que frequentemente inicia sucessão secundária em áreas abertas pela intensa germinação de suas sementes no solo. Estudos sobre espécies amazônicas de rápido crescimento são muito escassos, quando se refere à influência de fatores abióticos sobre a ecofisiologia. O experimento foi conduzido em casa de vegetação pertencente ao laboratório de Estudos da Biodiversidade de Plantas Superiores da Universidade Federal Rural da Amazônia. O experimento foi inteiramente casualizado em regime de parcelas divididas, dois tempos: cinco e dez dias de suspensão de água e duas condições de água: controle e déficit de água, com quatro repetições com uma planta/vaso. A condição de deficiência de água por dez dias afetou negativamente o crescimento e os indicadores de troca de gás $(A, g s e$ E). Adicionando ao fato de que o experimento ocorreu em um ano de anomalia climática extrema (El Niño), as plantas não resistiram e morreram nas condições internas de casa de vegetação. A condição de deficiência de água alterou os parâmetros de crescimento e as relações ambientais da espécie Tachigali vulgaris, evidenciando assim sua baixa plasticidade fisiológica a esta condição abiótica.

Palavras-chave: Fotossíntese, condutância, massa seca, Tachi branco. 


\section{INTRODUCTION}

Climate change directly correlated with increased $\mathrm{CO}_{2}$ concentration in the atmosphere and temperature can have diverse consequences for the human population and for global biodiversity (IPCC, 2014). These changes are mainly due to anthropic activity, such as industrialization, deforestation, mining and agriculture, among others. These activities provide significant warming of the planet, resulting in migrations of animal and plant species to higher latitudes and/ or altitudes in search of temperatures close to their natural condition. However, trees will not do so because of their slow migration and adaptability to the rapidity of climate change (Buckeridge, 2007).

Tachigali vulgaris is a pioneer species, colonizer of marginal lands and road margins, which often initiates secondary succession in open areas by the intense germination of their seeds in the soil. It has stood out for the rapid growth and its wood is widely used by rural communities of the Midwest and Northeast, in the construction of mourões, stands, packaging and rafters, in the civil construction, as well as a source for the production of firewood and charcoal (Franke, 1999). It is endemic to Brazil, where it is recorded in the Northeast, Midwest and North regions, occurring in the phytogeographical domains of the Caatinga, Cerrado and Amazon (Lima, 2012).

Studies on fast-growing Amazon forest species are very scarce, when it refers to the influence of abiotic factors on an ecophysiology of the species. These studies are important for a prior identification of the different strategies and mechanisms of adaptation of the species in relation to their production for the recommendation of areas of planning and as a function of change of global and regional climatic conditions (Morais et al., 2017).

The water deficit is considered the most limiting factor to the growth and development of the plants, occurring in a large area, especially in regions characterized by low rainfall and irregular distribution of rainfall (Melo et al., 2010). In response to the reduction of water availability for several woody species, many consequences can occur, such as low dry mass production, reduction in $\mathrm{CO}_{2}$ assimilation rate, stomatal conductance and transpiration.
The effects of climate change and its changes in ecosystems need to assess the impacts that these changes may have on an agricultural production on a regional scale (Morais et al., 2017). Considering the assumption, the present research aims to evaluate the growth and gas exchange in plants of Tachibranco in two periods of water suspension.

\section{MATERIAL AND METHODS}

\section{Characterization of the studied area}

The experiment was conducted in a greenhouse belong to laboratory of Studies on Biodiversity of Upper Plants in the Federal Rural University of Amazonia EBPS/UFRA, Belém-Pará (0127'21" $\mathrm{S}$ and $48^{\circ} 30^{\prime} 16^{\prime \prime} \mathrm{W}, 11,1 \mathrm{~m}$ altitude) during the months of April to August of the year 2015. The seedlings with four months old were purchased from Association of the Wood Exporting Industries of the State of Pará - AIMEX, and were transplanted to pots with a capacity of $4.5 \mathrm{~kg}$ of black soil substrate (see Table 1) and stayed for two months of acclimatization. In order to overcome the nutritional deficiency, nutrient solution (Hoagland

Table 1 - Embrapa Amazonia Oriental soil analysis. Substrate used during the experiment

\begin{tabular}{c|c|c|c|c|c|c|c|c}
\hline \multicolumn{7}{c}{ Soil analysis } \\
\hline Depth & pH & P & K & $\mathrm{Na}$ & $\mathrm{Ca}$ & $\mathrm{Ca}+\mathrm{Mg}$ & $\mathrm{Al}$ & $\mathrm{H}+\mathrm{Al}$ \\
\hline $\mathrm{cm}$ & water & \multicolumn{6}{c}{$\mathrm{mg} / \mathrm{dm}^{3}$} & \multicolumn{5}{c}{$\mathrm{cmol}^{3} \mathrm{dm}^{3}$} \\
\hline 20 & 5,1 & 2 & 71 & 17 & 0,9 & 1,3 & 0,7 & 4,95 \\
\hline
\end{tabular}

Table 2 -Applications of nutritious solution during the conduction of the experiment. 1st Application / $1 \mathrm{~L}$ of water; 2nd application / $0.5 \mathrm{~L}$ of water and 3rd application / $1 \mathrm{~L}$ of distilled water

\begin{tabular}{l|c|c|c|l|c|c}
\hline \multicolumn{2}{c|}{$1^{\text {st }}$ Aplication } & \multicolumn{2}{c|}{ 2 $^{\text {nd }}$ Aplication } & \multicolumn{2}{c|}{ 3 $^{\text {rd }}$ Aplication } & Units \\
\hline $\mathrm{CaCl}_{2}$ & 0.5 & $\mathrm{KNO}_{3}$ & 1 & $\mathrm{~K}_{2} \mathrm{SO}_{4}$ & 2 & $\mathrm{ml}$ \\
\hline $\mathrm{NH}_{4} \mathrm{NO}_{3}$ & 7 & $\mathrm{NH}_{4} \mathrm{NO}_{3}$ & 1.5 & $\mathrm{KH}_{2} \mathrm{PO}_{4}$ & 0.5 & $\mathrm{ml}$ \\
\hline $\mathrm{KH}_{2} \mathrm{PO}_{4}$ & 1 & & & $\mathrm{CaCl}_{2}$ & 2 & $\mathrm{ml}$ \\
\hline FeEDTA & 1 & & & $\mathrm{MgSO}_{4}$ & 1 & $\mathrm{ml}$ \\
\hline Micronutrient & 1 & & & $\mathrm{FeEDTA}$ & 1 & $\mathrm{ml}$ \\
\hline $\mathrm{MgSO}_{4}$ & 1 & & & $\mathrm{Micronutrient}$ & 1 & $\mathrm{ml}$ \\
\hline & & & & $\mathrm{KNO}_{3}$ & 5 & $\mathrm{ml}$ \\
\hline & & & & $\mathrm{NH}_{4} \mathrm{NO}_{3}$ & 2 & $\mathrm{ml}$ \\
\hline
\end{tabular}


and Arnon, 1950) was applied in three different concentrations, in accordance with Table 2.

The climate of the region, according to Köppen classification, is Aw, characterized by the occurrence of average anal precipitation of $2893 \mathrm{~mm}$ and average annual temperature in the range of $26.5^{\circ} \mathrm{C}$ (Costa, 2001).

The air temperature, relative humidity and the vapor pressure deficit (VPD) were measured by the Incoterm direct reading thermo-hygrometer and infrared gas analyzer.

\section{EXPERIMENTAL DESIGN AND CHARACTERIZATION OF THE EXPERIMENT}

The experimental was completely randomized in split plot scheme (two times: five and ten days of water suspension, and two water conditions: control and water deficit, with four replications and one plant/pot.

The plant height was performed, from the base of the collection to the apical bud. The measurement of diameter chest height $(\mathrm{DCH})$ was realized with help of digital pachometer model ZAAS precision and the number of leaves per plant realized by manual counting.

Shoot and root biomass were measured at each destructive harvest at 5 and 10 days of water deficit, after drying in a forced circulation oven at $70{ }^{\circ} \mathrm{C}$ for 72 hours.

The relative water content (RWC) was determined between 05:00 and 06:00h on each collection. The method used was that described by Slavick (1979), where 30 fresh leaf discs (10 mm diameter) were removed from each plant randomly, through a stainless-steel pourer, immediately determining the fresh mass (FM). The disks were then transferred to a petri dish containing $35 \mathrm{ml}$ of distilled water and left on the bench $\left(25^{\circ} \mathrm{C}\right)$ for 12 hours. The discs were then placed on filter paper to remove excess water and then weighed to determine the turgid mass (TM). Afterwards, the disks were placed in paper bags and placed in an oven $\left(70{ }^{\circ} \mathrm{C}\right)$ for 24 hours and the dry mass of the discs (DM) was determined. The results were expressed as a percentage, according to the following formula:

$R W C=(F M-D M) /(T M-D M) \times 100$.

The net photosynthetic rate $(\mathrm{Pn})$, stomatal conductance $\left(\mathrm{g}_{\mathrm{s}}\right)$, transpiration rate $(E)$, maximum natural photosynthetically active radiation (PAR) and atmospheric vapor pressure deficit (VPD) were evaluated by portable meter IRGA (Infra-red Gas Analyser/ADC equipaments - mod. LCi 6400, Hoddesdon, UK) under favorable environmental conditions, between 9:00 and 10:00h in the morning. The evaluations were done in all plants of all treatments $(n=12)$, one leaflet per plant placed inside the chamber, always in the median region of the fully expanded leaf. Each leaflet remained in equilibrium within the chamber for 1 to 2 minutes before the values were recorded and ten measurements were taken for plant mean.

An analysis of variance was applied to the results through the statistical package (Assistat 7.7 beta, 2015) and when significant difference occurred, the means were compared by the test $t$ adopting the level of $5 \%$ of probability.

\section{RESULTS AND DISCUSSION}

\section{Environmental variables}

The mean for the two evaluation periods for photosynthetically active radiation was 1000 umol. $\mathrm{m}^{-2} \cdot \mathrm{s}^{-1}$. The mean temperature throughout the experiment was $30.6{ }^{\circ} \mathrm{C}$ and the relative humidity was $81.5 \%$. The obtained VPD was 2.16 and $1.54 \mathrm{kPa}$ for the first and second points of data collection, respectively. The description of these environmental variables may directly or indirectly influence the physiological and biochemical variables throughout the experiment.

\section{Biometrical variables}

\section{$\underline{\text { Height }}$}

There was statistical difference only for water condition, obtaining the averages of 13.40 and $12.63 \mathrm{~cm}$ for the control and deficit treatments, 

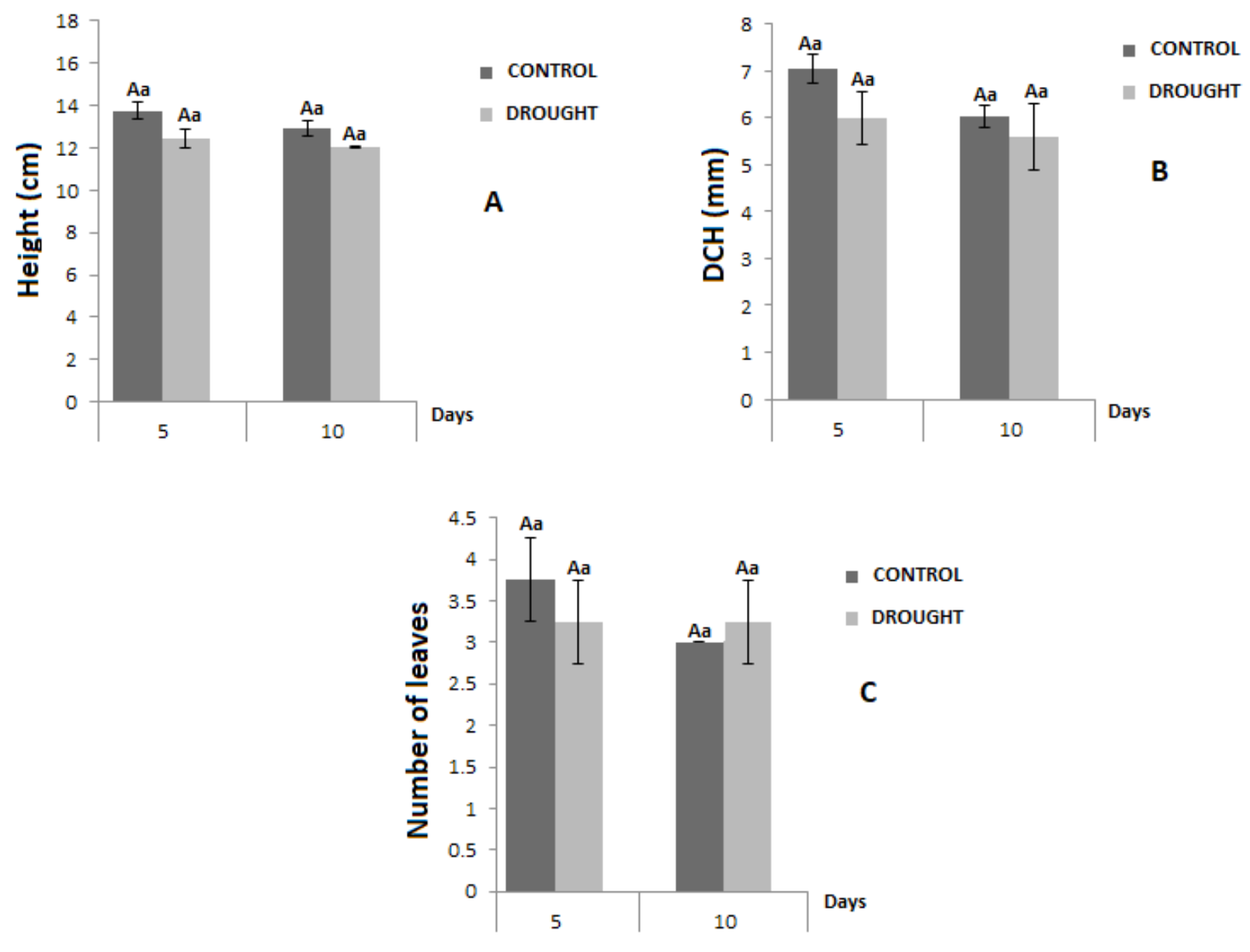

Figure 1 - Growth variables (A) height, (B) DCH and (C) number of leaves in seedling of Tachigali vulgaris, in function of drought, in two evaluation periods. Averages followed by the same letter do not differ statistically at the probability level. Lower case letters compare the values between the water regimes and the upper case letters compare the values throughout the experiment.

respectively. The stagnation of height growth was notorious (Figure 1A) when compared to the mean of the controls with the last point for plants under water deficit, reducing from 13.4 to $12.06 \mathrm{~cm}$, representing a reduction of $10 \%$ in the height.

According Jaleel et al. (2009), the water limitation is considered one of the most important stressors that limit the growth of plants. According to Jesus and Azevedo Neto (2013), the growth evaluation is a parameter used to evidence the tolerance of plants under stress. Maintaining turgescence is a necessary prerequisite for cell elongation and growth, and consequently limited water supply can cause large reductions in plant growth (Warren et al., 2012).
Although there was no statistical difference for the height variable, probably due to the short time of interval in the experiment, Roza (2010) points out that the pronounced loss of water reduces the multiplication and the elongation of the cells, resulting in plants with lower heights.

Nascimento et al. (2011) working with seedlings of Hymenaea courbaril also did not find statistical differences between the treatments after a period of 49 days of water suspension.

\section{$\underline{\mathrm{DCH}}$}

The DCH (Figure 1B) showed statistical differences only for treatment suspension times, with averages of 6.52 and $5.79 \mathrm{~mm}$ at 5 and 10 days of water 
suspension and for water regime, the averages of 6.72 and $5.98 \mathrm{~mm}$ in the control and water deficit, respectively. As the height, the $\mathrm{DCH}$ also showed an absolute reduction, from $6.71 \mathrm{~mm}$ in the control plants to $5.58 \mathrm{~mm}$ in the plant submitted to the water deficit on the tenth day of the experiment, representing a reduction of $16,84 \%$.

According to Lechinoski et al. (2007) the lack of water in the soil makes the variable as the diameter limiting to the growth of the vegetal species when submitted to the condition of water deficiency.

Almeida et al. (2005) evaluating the diameter at breast height in Hymenaea courbaril plants,observed statistical differences for the treatment with only $25 \%$ of the field capacity, evidencing in this way the influence of the water deficit in the biometric reduction of the plants.

\section{$\underline{\text { Number of leaves }}$}

The number of leaves (Figure 1C) did not present statistical difference for both treatments, both for the interaction and for the factors analyzed alone.

Due to the short time that the plants were submitted to water deficiency, the emission of new leaves was not influenced. Thus, it was not possible to verify difference. According to Silva and Nogueira (2003) woody species present reduction in the emission of new leaves after induction of water deficiency. Differing from this study, the same authors found significant differences between three woody species (Mimosa caesalpiniifolia, Prosopis juliflora and Tabebuia aurea), that showed reductions in the emission of new leaves when the plants were submitted to the water deficit.

\section{Relative Water Content}

The relative water content (Figure 2) presented a significant difference when comparing the control treatment with water deficiency, with a noticeable reduction from the fifth day of experiment, $85.31 \%$ to $66.07 \%$ of the water content in the foliar tissues of the control and water deficit plants, respectively. This decrease reflected directly in the photosynthetic activity (Figure 2) of the plants, and consequently in all metabolic processes of the plants. In the second data collection the percentage

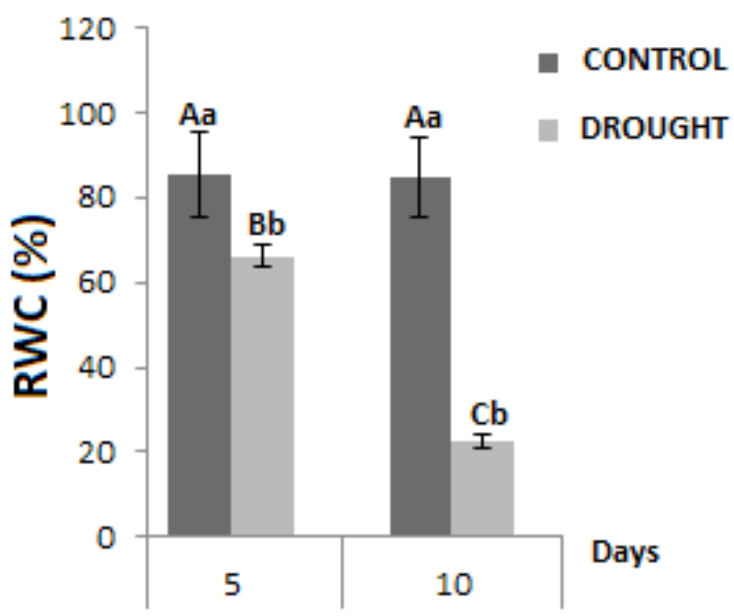

Figure 2 - Relative Water Content in leaves of Tachigali vulgaris, in function of drought, in two evaluation periods. Averages followed by the same letter do not differ statistically at the probability level. Lower case letters compare the values between the water regimes and the upper case letters compare the values throughout the experiment.

of water in the leaves was drastically reduced from 84.81 to $22.67 \%$ in the control and water deficit plants respectively, thus demonstrating that all free water from the leaf tissues had already been dissipated, remaining only hygroscopic water. This represented a reduction of $73.24 \%$ in RWC of plants in water deficit in relation to the control plant.

According to Pincelli (2010), the control of the physiological functions is directly related to the water status of the plant, where the changes in the RWC directly affect the photosynthetic apparatus, as it could be analyzed according to Figure 3 . If the dry period is prolonged, the water deficit can affect the crop, with reduction in plant height, relative water content and photosynthetic rate.

Rahimia (2010) evaluating the performance of two species of Plantago (Plantago ovata and P. psyllium) submitted to the water deficiency observed that both reduced the RWC from the 7th day after the suspension of the irrigation and finding values for RWC around $60 \%$.

As in this study, Coscolin (2012) pointed out a direct relationship between the reduction of RWC and in parallel with the reduction of growth 
parameters and gas exchange. Such reductions have seriously compromised plant metabolism, as we can observe through growth and gas exchange variables. Smit and Singels (2006) state that RWC values below 75\% already promote limitations in the physiological activities of plants. Pacheco (2011), when assessing the water deficit in Calendula officinalis, also observed a significant decrease in RWC, reaching an average value of $48.5 \%$.

\section{Photosynthesis}

The net photosynthesis (Pn) in Figure 3 showed after 5 days of water suspension a decrease from 2.44 to $0.15 \mu \mathrm{mol} . \mathrm{m}^{-2} . \mathrm{s}^{-1}$ from control to drought. Plants under 10 days water deficiency were already under severe water stress, with the value of the photosynthesis rate equal to zero, an event likely to have been accelerated due to the drastic reduction of water availability in the soil. The photosynthetic activity presented a reduction of $93.85 \%$ when comparing the control with the water deficit.

Regardless of the type of metabolism, water stress causes reduction in photosynthesis and increased respiration, promoting an increase in the production of reactive oxygen species (Pereira et al., 2012). Vítolo et al. (2012) state that when the plant undergoes some type of stress such as

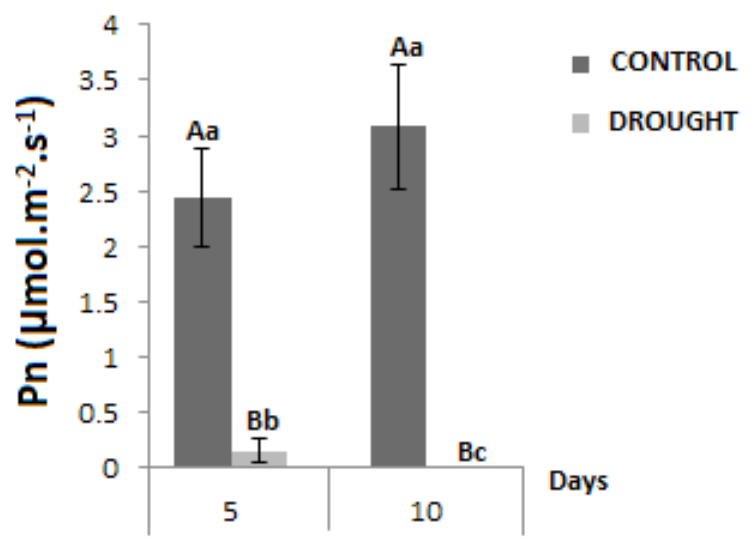

Figure 3 - Net photosynthesis ( $\mathrm{Pn}$ ) of Tachigali vulgaris, in function of drought, in two evaluation periods. Averages followed by the same letter do not differ statistically at the probability level. Lower case letters compare the values between the water regimes and the upper case letters compare the values throughout the experiment. water stress, photosynthesis, respiration, electron transport by the membrane and enzymatic activity are reduced when the functional integrity of the chloroplasts and mitochondrial membranes are affected.

When the plant is in a state of water stress, the stomata is closed in order to avoid the complete dehydration of the leaves, thus limiting the diffusion of $\mathrm{CO}_{2}$ to the leaf mesophyll, which leads to a decrease in photosynthesis (Chaves et al., 2009). Studies show that stomatal closure affects plant growth, since it promotes the reduction of photosynthetic rates, limiting phytomass production due to the low $\mathrm{CO}_{2}$ supply (Ashraf, 2010).

For Sanda et al. (2011), non-stomatal mechanisms at the chloroplast level, such as electron transport and photophosphorylation may be related to inhibition or reduction of photosynthesis. The photosystem II depends on water for the generation of chemical energy, required later for the fixation of $\mathrm{CO}_{2}$, variations in water availability generate less efficiency of photosystem II, that is, with limited water resources, less ATP and NADPH are formed and, as consequently, less $\mathrm{CO}_{2}$ is fixed at the carboxylation site (Pinheiro e Chaves, 2011).

The gas exchanges act on the energy balance of the leaves, participating in the regulation of their temperature, so as to leave it within the range of values appropriate to the physiological processes of the plants and their adaptation to the environment. The control of transpiration is performed by the stomatal closure, which is the only process in the soil-plant-atmosphere continuum that has this instantaneous response (Pincelli, 2010).

For all the variables of gas exchange it was possible to observe the leaflet folding in each leaf / plant. According to Oliveira (2014) foliar winding and folding are hydronastic mechanisms that reduce light interception, transpiration and leaf dehydration. It is suggested that for this reason all the gas exchange variables presented relatively low values, related to the environmental conditions at the time of the experiment, considering that at the end of the ten day period the plants were at a fairly advanced wilt point. 
Corroborating this study, Moraes (2011) evaluated different hybrids of eucalyptus under water deficiency found a statistical difference for the net photosynthesis $(\mathrm{P}<0.01)$ between irrigation and hybrids at the end of the suspension period.

\section{Stomatal conductance}

After five days of experiment, a statistical difference wasobserved for thestomatalconductance(Figure 4) in the plants under water deficit 0.0138 when compared to the control plants $0,096 \mu \mathrm{mol} \cdot \mathrm{m}^{-2} \cdot \mathrm{s}^{-1}$, remaining constant until the tenth day and falling even further 0.005 under water deficit, being directly proportional to the reduction of the RWC.

The physiological variables partially accompanied the rates of VPD and the photosynthetically active radiation, depending on the RWC. The behavior is not so evident when there is a greater increase of transpiration and stomatal conductance with the decrease of the VPD, since the photosynthetically active radiation did not oscillate so much throughout the experiment. However, this response decreases according to the water status of each plant, and therefore cannot be generalized to others.

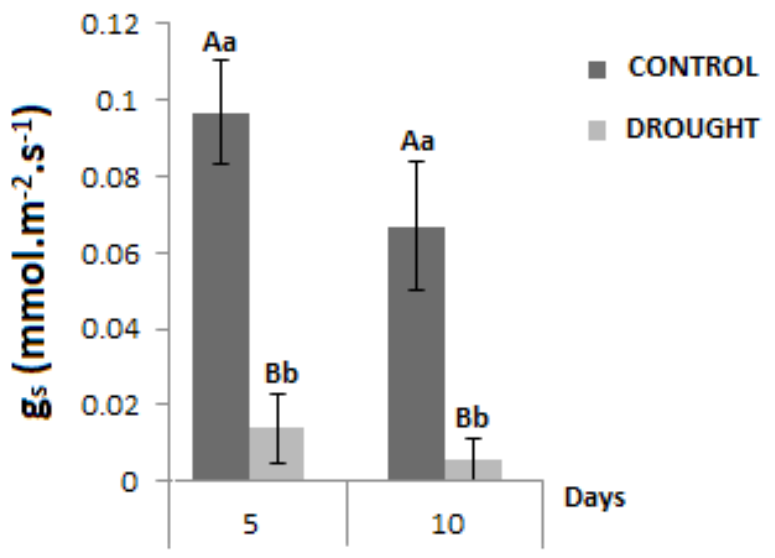

Figure 4 - Stomatal conductance (gs) in leaves of Tachigali vulgaris, in function of drought, in two evaluation periods. Averages followed by the same letter do not differ statistically at the probability level. Lower case letters compare the values between the water regimes and the upper case letters compare the values throughout the experiment.
In situations of low water availability in the soil, the plants minimize water losses by reducing the stomatal conductance, consequently negatively affecting the growth variables in absolute terms. The drop in $g s$ rates due to the gradual closure of the stomatal opening causes a decrease in $E$ in the treatment under water deficiency, due to the increase of the VPD during the day.

The physiological and biochemical responses vary according to the genotype, but in general the modifications related to water deficiency include the lower water potential in the soil and leaves, reflecting in the decrease of the stomatal conductance and photosynthetic rate (Polizel, 2007).

Due to the strong relation between the stomatal conductance and other photosynthetic parameters, we are led to point to gs as a reference character to evaluate the degree of water stress. Pita et al. (2005) state that stomatal conductance may be a useful tool in genetic improvement for selection for higher productivity in drought-prone environments, because stomatal conductance provides a crucial link between transpiration loss and carbon gain and, therefore, of the growth and between the saving of water by the closure of the stomata and greater heat stress.

According to Chagas et al. (2013) this reduction in response to the water deficit is related to a decrease in water content, for example, to the accumulation of abscisic acid in the leaves, leading to stomatal closure. Oliveira (2014) also observed that $E$ rates accompanied a reduction of $g s$ for both species Syagrus coronata and Acrocomia aculeata in drought conditions.

\section{Transpiration}

The plants presented significant differences for the transpiration (Figure 5) from the fifth day, with reductions of 1.8 for $0.3 \mathrm{mmol} . \mathrm{m}^{-2} . \mathrm{s}^{-1}$ for the control and water deficit treatments respectively, and from 1.3 for $0.1 \mathrm{~m}^{-2} . \mathrm{s}^{-1}$ to the tenth day, which represented a reduction of $76,92 \%$. It was demonstrated that transpiration was considerably reduced in the plants with lower water availability in the soil, reflecting the liquid assimilation rate, since the stomatal closure also causes a decrease in the $\mathrm{CO}_{2}$ 


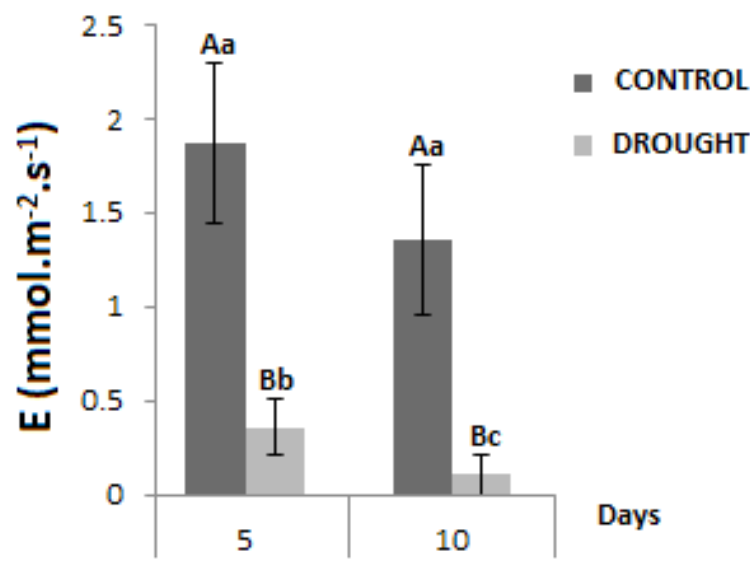

Figure 5 - Transpiration (E) in leaves of Tachigali vulgaris, in function of drought, in two evaluation periods. Averages followed by the same letter do not differ statistically at the probability level. Lower case letters compare the values between the water regimes and the upper case letters compare the values throughout the experiment.

input to the leaf mesophyll and the carboxylation site.

Another variable that correlates with transpiration is VPD, which increases with increasing transpiration, and responses vary between species and between genotypes of the same species (Kholová et al., 2010). According to Mota (2011), the gradual closure of the stomatal opening throughout the day causes a decrease of $g s$ and $E$, more pronounced in the treatment under water deficit, due to the increase of the VPD during the day, contrary to the behaviour of the VPD during the experiment. During the experiment the VPD was decreasing, however, the minimum level of water in the substrate had already been reached, which did not help in any way to mitigate the damage caused in the plants, since transpiration continued to be reduced fifth to the tenth day, and resulting in their death.

As recommended by Silva (2013), the transpiration process is directly associated to the stomatal conductance, responsible for the exchange of gases and vapours, with the reduction of the water potential, the stomatal closure causes a greater reduction of $\mathrm{H}_{2} \mathrm{O}$ flow out of the leaf than in the flow of $\mathrm{CO}_{2}$ that reaches the chloroplasts, decreasing the transpiration rate more than the photosynthetic rate (Rivas et al., 2013). Another important factor in responding to the low transpiration of $T$. vulgaris plants is the increase in biosynthesis or redistribution of $\mathrm{ABA}$, a hormone that promotes the reduction of transpiration, closing its stomata in plants under stress and is considered a chemical stress signal (Lima, 2015).

For Alves (2010), one of the causes of decreased transpiration can be attributed to the decrease in water supply due to the decrease in hydraulic conductivity of the roots or the death of roots, causing a decrease in the water potential of the leaves. This same author working with plants of Tabebuia serratifolia found reductions of $99 \%$ in the transpiration rates under water deficit in relation to the control plants.

\section{Shoot and root dry mass, and root/shoot ratio}

It was not possible to verify statistical difference for the treatments control and water deficiency of shoot (Figure 6A) and root (Figure 6B) dry mass, both for isolated factors and for the interaction between them. Although there was no statistically significant difference between the treatments, a higher biomass increment was observed in the root when compared to the shoot for the plants submitted to water deficit, with $4.67 \mathrm{~g}$ for the shoot and $7.44 \mathrm{~g}$ for the root.

Also for the root / shoot ratio (Figure 6C), there were no significant differences $(p>0.05)$ between the control and water deficit treatments, this behavior may be explained by the small time interval used in this experiment, presenting the averages of 1.22 and $1.25 \mathrm{~g}$ for the control and water deficit treatments at day 5 and 1.42 and $1.44 \mathrm{~g}$ at the 10th day.

For Pereira et al. (2003) it is very important to evaluate root and shoot growth, based on dry matter accumulation and leaf area increase. For the indices determined in the growth analysis indicate the capacity of the assimilatory system of the plants to synthesize (source) and to allocate the organic matter in the various organs (drains) that depend on the photosynthesis, respiration and translocation of photoassimilates of the sites of fixation of carbon, to the places of use or storage, where there is growth and differentiation of organs (Fontes et al., 2005). 

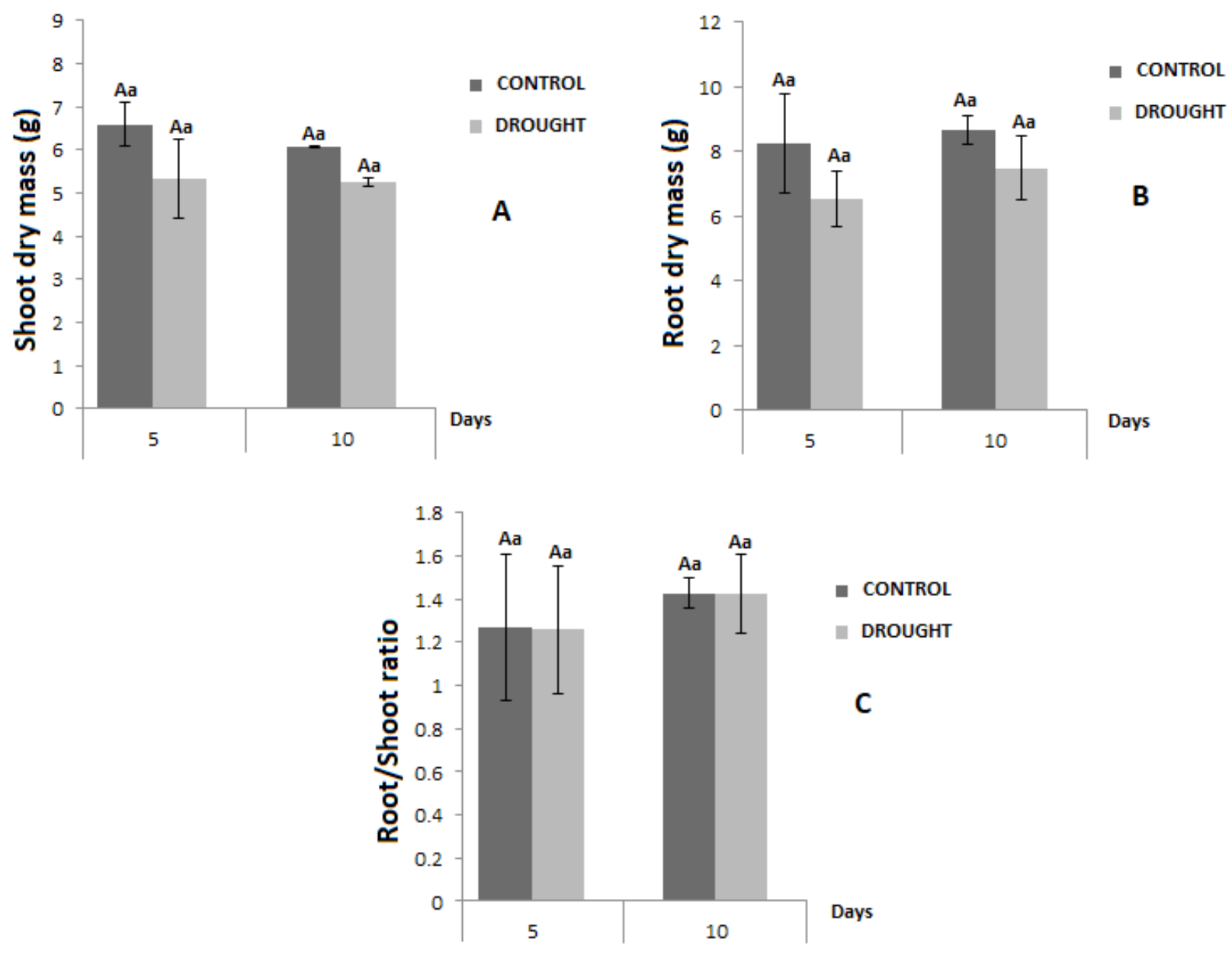

Figure 6 - Shoot dry mass (A), root dry mass (B) and root/ shoot ratio (C) in plants of Tachigali vulgaris, in function of drought, in two evaluation periods. Averages followed by the same letter do not differ statistically at the probability level. Lower case letters compare the values between the water regimes and the upper case letters compare the values throughout the experiment.

Moraes (2011) working with eucalyptus plants found similar results, with the biomass of the lower aerial part to the root when the plants were submitted to the water deficit. In relation to root growth, some forest species tend to increase root growth after submission of the water deficit (Nascimento, 2013). According to Larcher (2006) in adverse situations, the root growth may be higher than the aerial part, especially in drought situations, as they expand their roots to deeper soil regions in search of water.

The same explanation can be attributed to the root / shoot ratio, even if there was no statistical difference a greater increase of the root in relation to the aerial part could be observed, in the attempt to expand its volume in the soil to fetch water and nutrients.

Suassuna et al. (2012) found increases in the root/ shoot ratio in some citrus genotypes also submitted to water deficiency, differing in this way with the research developed here.

\section{CONCLUSION}

The water deficiency condition for ten days negatively affected the growth and indicators of gas exchange (A, gs and E). Adding to the fact 
that the experiment occurred in a year of extreme climatic anomaly (El Niño), the plants did not resist and perished in the internal conditions of greenhouse.

The water deficiency condition altered the growth parameters and the environmental relations of the Tachigali vulgaris species, thus evidencing its low physiological plasticity to this abiotic condition.

\section{ACKNOWLEDGEMENTS}

The authors are grateful to the Group of Studies on Biodiversity in Upper Plants of the Federal Rural University of Amazônia for the collaborations of researchers and Coordination for the Improvement of Higher Education Personnel (CAPES).

\section{REFERENCES}

Almeida, Z.; Silvia, M.; Soares, A.M.C., Evaristo, M.; Vieira, C.V. and Bordignon, G.E. (2005) - Alterações morfológicas e alocação de biomassa em plantas jovens de espécies florestais sob diferentes condições de sombreamento. Ciência Rural, vol. 35, n. 1, p. 62-68. http://dx.doi.org/10.1590/S0103-84782005000100010

Alves, G.A.R. (2010) - Aspectos ecofisiológicos, bioquímicos e crescimento de plantas jovens de Ipê amarelo (Tabebuia serratifolia (Vahl) Nicholson) em condições de déficit hídrico e alagamento. Tese de Doutorado. Belém/PA, Universidade Federal Rural da Amazônia, 73 p.

Ashraf, M. (2010) - Inducing drought tolerance in plants: some recent advances. Biotechnology Advances, vol. 28, n. 1, p. 169-183. https://doi.org/10.1016/j.biotechadv.2009.11.005

Buckeridge, M.S. (2007) - Mudanças climáticas, biodiversidade e sociedade: como a teoria de redes pode ajudar a compreender o presente e planejar o futuro? Multiciência, vol. 8, p. 88-107.

Chagas, J.R.M.; Kelly, N.N.C.; Barbosa, M.A.M.; Barbosa, J.R.S.; Pereira, T.S.; Viana, G.D.M. \& Lobato, A.K.S. (2013) - Condutância estomática em plantas jovens de Euterpe oleracea (Arecaceae) sob déficit hídrico. In: $64^{\circ}$ Congresso Nacional de Botânica. Belo Horizonte/MG.

Chaves, M.M.; Flexas. J. \& Pinheiro, C. (2009) - Photosynthesis under drought and salt Stress: Regulation mechanisms from whole plant to cell. Annals of Botany, vol. 103, n. 4, p. 551-560. https://doi.org/10.1093/aob/ men125

Coscolin, R.B.S. (2012) - Efeitos fisiológicos e bioquímicos induzidos por deficiência hídrica em plantas de Ocimum basilicum L. Dissertação Mestrado. Universidade Estadual Paulista, 96 p.

Costa, A.C.L. (2001) - Estudos de variações termohigrométricas de cidade equatorial devido ao processo de urbanização: O caso de Belém-PA. 2001. Tese de doutorado. São Carlos/SP, Universidade de São Paulo - Escola de Engenharia de São Carlos. 236 p.

Fontes, P.C.R.; Dias, E.N. \& Silva, D.J.H. (2005) - Dinâmica do crescimento, distribuição de matéria seca na planta e produção de pimentão em ambiente protegido. Horticultura Brasileira, vol. 23, p. 94-99.

Franke, I.L. (1999) - Principais usos e serviços de árvores e arbustos promissores que ocorrem em pastagens no estado do Acre. Comunicado Técnico: EMBRAPA/AC, n. 106, p. 1-6.

Hoagland, D.R. \& Arnon, D.I. (1950) - The water culture method for growing plants without soil. California Agricultural Experiment Station Publications p. 137-147.

IPCC (2014) - Synthesis Report. Contribution of Working Groups I, II and III to the Fifth Assessment Report of the Intergovernmental Panel on Climate. Geneva, Switzerland, $151 \mathrm{p}$.

Jaleel, C.A.; Paramasivam, M.; Abdul, W.; Muhammad, F.; Hameed, J.A.; Ramamurthy, S. \& Rajaram, p. V. (2009) - Drought stress in plants: A review on morphological characteristics and pigments composition. International Journal of Agriculture and Biology, vol. 11, n. 1, p. 100-105.

Jesus D.S. \& Azevedo Neto, A.D. (2013) - Aluminum Tolerance in Sunflower Plants Is Associated with Phosphorus Content in the Roots. Communications in Soil Science and Plant Analysis, vol. 44, n. 22, p. 34233430. http://dx.doi.org/10.1080/00103624.2013.847453

Kholová, J.; Hash C.T.; Kumar, P.L.; Yadav, R.S.; Kocová, M. \& Vadez, V. (2010) - Terminal drought-tolerant pearl millet [Pennisetum glaucum (L.) R. Br.] have high leaf ABA and limit transpiration at high vapour 
pressure deficit. Journal of Experimental Botany, vol. 61, n. 5, p. 1431-1440. https://doi.org/10.1093/jxb/erq013

Larcher, W. (2006) - Ecofisiologia Vegetal. CHBA. Ed Rima, São Carlos. 531 p.

Lechinoski, A.; Freitas J.M.N.; Castro, D.S.; Lobato, A.K.S.; Oliveira Neto, C.F. e Moraes, R.L. (2007) Influência do Estresse Hídrico nos Teores de Proteínas e Aminoácidos Solúveis Totais em Folhas de Teca (Tectona grandis L. f.). Revista Brasileira de Biociências, vol. 5, sup. 2, p. 927-929.

Lima, E.G.S. (2015) - Respostas ecofisiológicas e bioquímicas em folhas de Andiroba (Carapa guianensis Aubl) sob três regimes hídricos e suspensão dos estresses.Dissertação Mestrado. Universidade Federal Rural da Amazônia. $92 \mathrm{p}$.

Lima, H.C. (2012) - Tachigali. Lista de Espécies da Flora do Brasil. Jardim Botânico do Rio de Janeiro, Rio de Janeiro.

Melo, A.S.; Suassuna, J.F.; Fernandes, P.D.; Brito, M.E.B.; Suassuna, A.F. \& Netto, A.O.A. (2010) - Crescimento vegetativo, resistência estomática, eficiência fotossintética e rendimento do fruto da melancieira em diferentes níveis de água. Acta Scientiarum: Agronomy, vol. 32, n. 1, p.73-79. http://dx.doi.org/10.4025/ actasciagron.v32i1.2136

Moraes, J.V. (2011) - Parâmetros biométricos, fisiológicos e bioquímicos em híbridos de Eucalyptus grandis $x$ Eucalyyptus urophilla sob diferentes regimes de irrigação em casa de vegetação. Tese de Doutorado. São Paulo/ SP, Faculdade de Ciências Agrárias e Veterinárias - UNESP.

Morais, R.R.; Rossi, L.M.B. \& Higa, R.C.V. (2017) - Trocas gasosas de plantas jovens de taxi-branco submetidas à variação de temperatura foliar e suspensão da irrigação. Ciência Florestal, vol. 27, n. 1, p. 97-104. http:// dx.doi.org/10.5902/1980509826450

Mota, C.S. (2011) - Características fotossintéticas da palmeira Macaúba (Acrocomia aculeata (Jacq.) Lodd. ex Mart.) submetida à deficiência hídrica. Tese Doutorado.Viçosa/MG, Universidade Federal de Viçosa, p. 85.

Nascimento, H.H.C.; Nogueira, R.J.M.C.; Silva, E.C. \& Silva, M.A. (2011) - Análise do crescimento de mudas de jatobá (Hymenaea courbaril L.) em diferentes níveis de água no solo. Revista Árvore, vol. 35, n. 3, p. 617626. http://dx.doi.org/10.1590/S0100-67622011000400005

Nascimento, H.H.C. (2013) - Mecanismos fisiológicos e bioquímicos em mudas de Jatobá (Hymenaea courbaril L) sob condições adversas. Tese Doutorado. Universidade Federal Rural de Pernambuco, Recife/PE, 162 p.

Oliveira, D.A.S. (2014) - Respostas ecofisiológicas e morfoanatômicas de Licuri e Macaúba sob condições de campo. Dissertação (Mestrado). Universidade Federal de Pernambuco. Recife/PE. 54 p.

Pacheco, A.C.; Camargo, P.R. \& Souza, C.G.M. (2011) - Deficiência hídrica e aplicação de ABA nas trocas gasosas e no acúmulo de flavonoides em Calêndula (Calendula officinalis L.). Acta Scientiarum: Agronomy, vol. 33, n. 2, p. 275-281. http://dx.doi.org/10.4025/actasciagron.v33i2.6390

Pereira, J.W.; Melo Filho, P.A.; Albuquerque, M.B.; Nogueira, R.M. \& Santos, R.C. (2012) - Mudanças bioquímicas em genótipos de amendoim submetidos a déficit hídrico moderado. Revista Ciência Agronômica, vol. 43, n. 4, p. 766-773. http://dx.doi.org/10.1590/S1806-66902012000400019

Pereira, W.E.; Siqueira, D.L. de \& Puiatti, M. (2003) - Growth of citrus rootstocks under aluminium stress in hydroponics. Scientia Agricola, vol. 60, n. 1, p. 31-41. http://dx.doi.org/10.1590/\$0103-90162003000100006

Pincelli, R.P. (2010) - Tolerância à deficiência hídrica em cultivares de cana-de-açúcar avaliada por meio de variáveis morfofisiológicas. Dissertação Mestrado. Faculdade de Ciências Agronômicas, Universidade Estadual Paulista, Botucatu, 78 p.

Pinheiro, C. \& Chaves, M.M. (2011) - Photosynthesis and drought: can we make metabolic connections from available data? Journal of Experimental Botany, vol. 62, n. 3, p. 869-882. https://doi.org/10.1093/jxb/erq340

Pita, P.; Cañas, I.; Soria, F.; Ruiz, F. \& Toval, G. (2005) - Use of physiological traits in tree breeding for improved yield in drought-prone environments. The case of Eucalyptus globulus. Forest Systems, vol. 14, n. 3, p. 383-393. http://dx.doi.org/10.5424/srf/2005143-00931

Polizel, A.M. (2007) - Avaliações moleculares, morfo-anatômicas e fisiológicas de soja geneticamente modificada com a construção rd29:DREB1A de Arabidopsis thaliana, visando tolerância à seca. Dissertação Mestrado. Universidade Estadual de Londrina. Londrina, $125 \mathrm{p}$.

Rahimia, A.; Hosseini, S.M.; Pooryoosef, M. \& Fateh, I. (2010) - Variation of leaf water potential, relative water content and SPAD under gradual drought stress and stress recovery in two medicinal species of Plantago ovata and p. psyllium. Plant Ecophysiology, vol. 2, p. 53-60. 
Rivas, R.; Oliveira, M.T. \& Santos, M.G. (2013) - Three cycles of water deficit from seed to young plants of Moringa oleifera woody species improves stress tolerance. Plant Physiology and Biochemistry, vol. 63, p. 200208. https://doi.org/10.1016/j.plaphy.2012.11.026

Roza, F.A. (2010) - Alterações morfofisiológicas e eficiência de uso da água em plantas de Jatropha curcas L. submetidas à deficiência hídrica. Dissertação Mestrado - Universidade Estadual de Santa Cruz. Ilhéus - Bahia, 67 p.

Sanda, S.; Yoshida, K.; Kuwano, M.; Kawamura, T.; Munekage, Y.N.; Akashi, K. \& Yokota, A.(2011) Responses of the photosynthetic electron transport system to excess light energy caused by water deficit in wild watermelon. Physiologia Plantarum, vol. 142, n. 3, p. 247-264. https://doi.org/10.1111/j.1399-3054.2011.01473.x

Silva, E.C.A. (2013) - Respostas fisiológicas, bioquímicas e enzimáticas em mudas de Moringa oleifera Lam submetidas a estresses abióticos. Dissertação Mestrado. Universidade Federal Rural de Pernambuco, 102 p.

Silva, E.C. \& Nogueira, R.J.M. (2003) - Crescimento de quatro espécies lenhosas cultivadas sob estresse hídrico em casa-de-vegetação. Revista Ceres, vol. 50, n. 288, p. 203-217.

Slavick, B. (1979) - Methods of studying plant water relations. New York: Springer Verlag, 449 p.

Smit, M.A. \& Singels, S. (2006) - The response of sugarcane canopy development to water stress. Field Crops Research, vol. 98, n. 2-3, p. 91-97. https://doi.org/10.1016/j.fcr.2005.12.009

Suassuna, J.F.; Fernandes, P.D.; Nascimento, R.; Oliveira, A.C.M.; Brito, K.S.A. \& Melo, A.S. (2012) - Produção de fitomassa em genótipos de citros submetidos a estresse hídrico na formação de porta-enxerto. Revista Brasileira de Engenharia Agrícola e Ambiental, vol. 16, n. 12, p. 1305-1313. http://dx.doi.org/10.1590/S141543662012001200007

Vítolo, H.F.; Souza, G.M. \& Silveira, J.A.G. (2012) - Cross-scale multivariate analysis of physiological responses to high temperature in two tropical crops with $\mathrm{C} 3$ and $\mathrm{C} 4$ metabolism. Environmental and Experimental Botany, vol. 80, p. 54-62. https://doi.org/10.1016/j.envexpbot.2012.02.002

Warren, C.R.; Aranda, I. \& Cano, F.J. (2012) - Metabolomics demonstrates divergent responses of two Eucalyptus species to water stress. Metabolomics, vol. 8, n. 2, p. 186-200. https://doi.org/10.1007/s11306-011-0299-y 